\title{
Identification of Customer's Preferences as One of the Main Activities of Destination Management
}

\author{
Miriam Garbarova ${ }^{1}$, Lukas Vartiak ${ }^{2}$ \\ ${ }^{1}$ University of Zilina, Faculty of Operation and Economics of Transport and Communications, \\ Department of Communications, Univerzitna 8251/1, 01026 Zilina, Slovakia \\ ${ }^{2}$ Comenius University, Faculty of Social and Economic Sciences, Institute of Mediamatics, \\ Mlynske luhy 4, 82105 Bratislava, Slovakia
}

\begin{abstract}
The paper deals with destination management and its use in attracting visitors. Its main goal is to identify the factors influencing the visitor when choosing a destination. For the purpose of the paper, the destination represents a significant factor in customers' preferences when purchasing a tourism product. The aim is to be fulfilled by the primary research. Methods of excerpting, synthesis, induction, analysis, comparison and questioning were used. As a result, customer's preferences riven according to segmentation were identified.
\end{abstract}

Keywords - Destination Management, Tourism, Destination, Preferences.

\section{Introduction}

Currently, there is stronger competition between destinations, so the destinations strive to differentiate

DOI: $10.18421 /$ TEM111-18

https://doi.org/10.18421/TEM111-18

Corresponding author: Miriam Garbarova, University of Zilina, Faculty of Operation and Economics of Transport and Communications, Department of Communications, Zilina, Slovakia.

Email: miriam.garbarova@fpedas.uniza.sk

Received: 01 November 2021.

Revised: 10 January 2022.

Accepted: 16 January 2022.

Published: 28 February 2022.

(cc) BY-NC-ND (C) 2022 Miriam Garbarova \& Lukas Vartiak; published by UIKTEN. This work is licensed under the Creative Commons Attribution-NonCommercial-NoDerivs 4.0 License.

The article is published with Open Access at www.temjournal.com themselves somehow and attract a potential customer and thus gain a competitive advantage.

For this reason, destination management organizations have gradually emerged, which focus on coordinating tourism activities in a particular destination.

The basis of successful activity planning is to know the customer and his needs well. In the case of destination management, it is necessary to know in detail the target segment of the destination, the preferences and interests of its visitors and what motivates them to visit. Destination management activities examine the attractiveness of the destination and then segment and promote the specific destination.

The paper is divided into introduction, theoretical background, methodology, results and discussion, and conclusion. The first part represents input into the topic. The second part comprises definitions of the main terms, such as destination management, tourism, tourism activity and destination. The third part summarizes the methodology of creating the paper. Forth part presents results and includes a discussion about the results based on the segmentation. The last part is aimed at the recapitulation of the achieved results and disputes about recommendations, and limitations of the future research.

\section{Theoretical Background}

The term destination management is understood as a management organization of a specific tourist area and as certain processes. In Europe, destination management organizations replaced previous organizational structures in successful destinations abroad as early as the 1990s. "Destination management is labelled to be the most sophisticated tourism management. In foreign countries destination management develops even further, it develops to the 
level of destination governance and further to the newest approach which is destination leadership" [1].

With more modern approaches to tourism management and marketing, these organizations are considered the most developed form of tourism management today. The aim of the establishment of destination management organizations is to increase the number of visitors in the destination permanently, the visitor's expenses during the stay, increase the number of returning visitors, and extend the number of days spent in the destination [2].

Destination management objectives are to establish good cooperation among the public, private and nonprofit sectors, to provide effective financial flows in tourism, and coordination of all service provider cooperation. "Destination management should represent interests of tourists but as well interests of visited destinations' inhabitants, and all this should work under the condition of sustainable tourism" [1].

In terms of destination management, it is clear that tourists are a very important stakeholder group. They can influence tourist-centers and that is why the focus of destination management is on them and the need to manage the impacts tourists generate. "While such issues have been dealt with in the large but rather fragmented body of work relating to satisfaction, quality evaluation and impact assessment, there appears to have been little or no attempt as yet to address the broader question of what tourists actually think about destination management." Furthermore, understanding tourists' attitudes to destination management and why it is necessary for them may also contribute to the achievement of destination management aims [2].

Destination management is closely related to terms tourism, tourism activity, tourism product and destination.

According to the definition of the World Tourism Organization, tourism is the activity of people who travel temporarily to a place outside their typical environment in which they live, and the purpose of the journey is not to engage in gainful activity. Tourism can also be characterized as a set of activities to meet the needs related to travel and living outside the place of residence. These activities can be relaxation, entertainment, learning, cultural and social activities, etc. [3].

Tourism activities result in visiting a particular destination, which is defined as "a place with appropriate attractions concerning the tourist facilities and services that a tourist has chosen to visit" [4]. Furthermore, the Glossary of Tourism explains the term destination as "an area in a given region, which is characterized by a significant offer of tourist attractions and infrastructure. "In the broadest sense, a destination represents a tourism infrastructure, which results in a sizeable long-term concentration of visitors" [5].

For a foreign visitor, the destination can be the whole country or just a region of it. In some countries, the territory is divided into tourist, historical or administratively related destinations, creating and promoting a joint product of the region [4].

To summarize, the term destination is often used quite loosely. It can be understood as a particular administratively defined area, a purposefully created territorial unit (association of municipalities, microregion), a protected area (National Park) or a culturally and historically determined area [6].

Entities operating in tourism should have clearly defined factors that influence the environment in which they operate. Ryglova et al. [7] classified these factors into localization factors, implementation factors and selective factors.

Localization factors include natural and social activities. They are connected to a specific territory and therefore cannot be changed. They are made up of natural conditions, animals living in the area, vegetation, natural phenomena and attractions. Localization factors also include customs, traditions, rituals of people living in the area, and monuments [7].

Many kinds of research [8], [9], have confirmed that the more exciting and attractive localization factors are, the stronger the bond between visitors and the region is.

When promoting tourism in a certain region, it is necessary to adapt marketing activities to promote this region [10], [11]. Determining localization factors is very important for effective destination marketing. It is necessary to clearly distinguish the specifics of individual areas and thus ensure a clear differentiation of the territory. Localization factors determine how the region will be promoted and its competitive advantages compared to other regions [7], [12].

Other factors influencing tourism are implementation factors. They are essential because they enable the efficient use of the territory. They allow access and subsequent use of the destination. The visitor often decides to visit a given destination according to how fast and how well it is possible to get there. Also, the quality and quantity of products the region can provide (catering, transport and other services) are essential [7].

When deciding on a visit to the region, the visitor is also influenced by selective factors. They are related to consumer behavior and divided into objective and subjective factors. Objective factors include political, economic, demographic and administrative conditions. Subjective factors are mainly psychological factors that influence consumer 
decisions [7], [13]. Sustainable advertising, promotion, image, and the experience and reviews of other consumers play an important role in this case [14].

\section{Methodology}

The paper aims to identify the factors influencing the visitor when choosing a destination. For the purpose of the paper, the destination represents a critical factor in the process of purchasing a tourism product. The aim is to be fulfilled by the primary research consisting of the analysis and evaluation of a questionnaire. The primary research focused on visitors' preferences when choosing a destination. It was conducted through an online questionnaire created using Google Forms. Data collection was carried out via the social network Facebook from $1^{\text {st }}$ of May 2021 to $9^{\text {th }}$ of May 2021.

To perform the research, it was first necessary to determine the sample size. Given that the basic statistic set was larger than 100,000 , the following relationship was used to calculate the sample size [15]:

$$
\begin{aligned}
& n \geq t_{1-\frac{\alpha}{2}}^{2} * \frac{\sigma^{2}}{\Delta^{2}} \\
& \sigma=\sqrt{p^{*}(1-p)}
\end{aligned}
$$

where:

- $\mathrm{n}$ - minimum sample size (minimum number of respondents),

- $\mathrm{t}_{1-\alpha / 2}$ - critical value determined from statistic tables (1.96),

- $\sigma 2$ - variance calculated from the standard deviation,

- $\mathrm{p}$ - variability of the basic statistic set (character share),

- $\Delta$ - maximum permissible error range (0.05).

The required deviation in the implementation of our research was $\pm 5 \%$ and the required confidence interval was $95 \%$.

$$
\begin{aligned}
& \sigma=\sqrt{0,5 *(1-0,5)}=0,5 \\
& n \geq 1,96^{2} * \frac{0,5^{2}}{0,05^{2}}=384,16
\end{aligned}
$$

Based on the calculation, the minimum number of respondents needed for primary research was 385 . The proportion of the sample size was thus met, so 426 respondents participated in the online survey.

The introductory part of the questionnaire consisted of 4 identification questions regarding the gender of the respondents, their age, social status and region of origin:
- $62.2 \%$ of the respondents were women, and $37.8 \%$ were men.

- The category of respondents represented $41.8 \%$ of the respondents under 25 years of age, $20.4 \%$ of the respondents were aged from 36 to 45 , $11.3 \%$ of the respondents were aged from 26 to 35 years, $10.3 \%$ of the respondents were aged 65 years and more, $8.2 \%$ of the respondents were aged from 46 to 55 years respectively, $8.0 \%$ of the respondents were aged from 56 to 65 years.

- When considering the social status of the respondents, it consisted of $38.5 \%$ of employees, $35.0 \%$ of students, $13.8 \%$ of retirees, $5.2 \%$ of unemployed people, $3.8 \%$ of people on maternity/paternity leave and $2.8 \%$ of selfemployed people.

- Respondents originated from the Žilina Region $(17.4 \%)$, Prešov region $(16.4 \%)$, Košice region $(14.1 \%)$, Nitra region $(13.4 \%)$, Trenčín region $(11.3 \%)$, Banská Bystrica region (10.8\%), Bratislava region $(10.6 \%)$ and Trnava region $(5.9 \%)$.

In order to achieve the paper's aim, it was necessary to use several research methods:

- Excerpting - this method was used in the processing of theoretical background, while it is used to study the issue from book and Internet sources;

- Synthesis - this method was used to combine the acquired knowledge into one whole;

- Induction - this method was used to process the results of primary research and to determine its outputs;

- Analysis - this method was used in the collection of secondary data in order to define the destination management in detail;

- Comparison - this method was used in the processing of theoretical background and results;

- Questioning - the method of questioning was used in the implementation of primary research in the form of an online questionnaire.

\section{Results and Discussion}

One of the primary research aims was to find out with whom respondents travelled on holidays or trips. Almost half of the respondents stated that they travelled with their family, $27.2 \%$ travelled with a partner, $16 \%$ travelled with friends, $3.5 \%$ travelled with children, and $2.1 \%$ of respondents travelled alone.

It was interesting to find out that most respondents preferred one-week stays (43.4\%). Stays longer than a week were favoured by $25.1 \%$ of respondents, and $21.4 \%$ of respondents chose 2-nights stays. Only 
$7.5 \%$ of respondents preferred one day-long stays, and $2.6 \%$ of respondents preferred single-night stays.

When it comes to factors that most influence the respondents when choosing a destination, the quality of accommodation was the most important criterion for respondents, followed by the stay price. The third most important criterion was transport accessibility. This was followed by gastronomy, information about the region, historical monuments, parking, sports and recreational services, wellness services, cultural and social events and the destination brand.

The price of individual services played an essential role in choosing a destination, too. The answers of the respondents show that the price of accommodation played the most crucial role. It was followed by the price of meals, the price of admission, parking, and additional services.

When considering sources of information about the destination, up to $84.0 \%$ of respondents found information about the destination from official websites, $63.6 \%$ of respondents obtained information from acquaintances, $57.0 \%$ of respondents said they preferred social networks when obtaining information, and $40.4 \%$ of respondents used their experience. Information leaflets and brochures as sources of information were picked by $19.0 \%$ of respondents, $14.3 \%$ of respondents used tourist information centers, $14.1 \%$ of respondents obtained information from television, $10.3 \%$ of respondents found information in newspapers and magazines, $5.6 \%$ of respondents used printed guides, $3.5 \%$ of respondents followed the regional press and $3.1 \%$ of respondents used radio, fairs and exhibitions in the same proportion. In addition to the options mentioned above, respondents stated that they also used travel agencies and blogs to obtain information.

When buying a tourism product, $36.2 \%$ of respondents preferred the destination's website, $26.8 \%$ of respondents liked booking through a travel agency, $21.1 \%$ used discount portals, $7 \%$ shopped through social networks, $5.2 \%$ through tourist information centers, and $3.8 \%$ of respondents used another option.

Respondents showed the most significant interest in a stay package including residential and catering services, which was identified by $42.7 \%$ of them. This was followed by a spa package with $16.7 \%$, while $16.0 \%$ of respondents were interested in the wellness package and $15.5 \%$ of respondents preferred a sightseeing trip focused on visiting and exploring castles. Respondents were least interested in the ski package with accommodation and transport included in the price $(7.3 \%)$.

To summarize, respondents who go on holidays and trips with their family or partner prefer weekly stays and stays longer than a week. Respondents who go on holiday with friends are not used to spending more than a week on holiday.

The price of accommodation plays a vital role for all types of respondents. The price of meals is not decisive when choosing a destination, especially for young people under the age of 25 . The price of parking is important when choosing a destination, especially for people of productive age from 26 to 45 years.

Young people under the age of 25 prefer official destination websites and social networks when obtaining information about the destination. They buy stays mainly on the websites of destinations or via discount portals and travel agencies. They are primarily interested in one-week stays and wellness packages.

People aged from 26 to 35 mainly use destination websites and discount portals to buy tourism products, and they obtain information about these products mainly from destination websites and social networks. They are primarily interested in wellness packages.

Respondents aged from 36 to 45 do not attach much importance to the choice of destination for cultural and social events in the region, transport accessibility or destination brand. Also, the price of additional services, such as rental of bicycles and skis, is very important for them. The purchase of a tourism product is carried out mainly through destination websites, travel agencies and discount portals.

For respondents aged from 46 to 55, sports and recreational services, and cultural and social events offered by the region were unimportant when choosing a destination. The price of additional services is also not decisive. They purchase tourism products through destination websites, travel agencies and discount portals. They prefer trips aimed at exploring the region.

Older respondents over the age of 56 mainly use spa and wellness packages and buy tourism mainly via travel agencies.

\section{Conclusion}

The paper aimed to identify the factors influencing the visitor when choosing a destination. The destination was considered an essential factor in the process of purchasing a tourism product. The aim was fulfilled by the primary research consisting of the analysis and evaluation of a questionnaire.

The questionnaire, which 426 respondents filled in, showed that the decision to visit the destination is influenced mainly by the price, which followed the criterion of accommodation quality and transport accessibility. It is interesting that visitors went on holidays and trips most often with their family and preferred weekly stays. Respondents obtained 
information about destinations mainly from official destination websites and social networks. Many respondents said that they gained information about destinations from their acquaintances in addition to traditional sources of information. The purpose visitors travelled to the chosen destination was pure tourism, visiting cultural and historical monuments and recreation.

The recommendation from the point of view of destination management is wider sharing of information about the destination, the improvement and attractiveness of the offer for the given destination (for example, the progress of transport accessibility and the construction of cycle routes). The results provided space for future research focused on other destination management activities taking current tourism trends into account.

\section{Acknowledgements}

The paper was undertaken as a part of the research project 2/KS/2021 Mapping of selected areas of cultural and creative industry in the city of Zilina.

\section{References}

[1]. Becková, H., \& Nováková, B. (2016). Destination management: theoretical background and present practice. In The 10th International Days of Statistics and Economics: conference proceedings. Melandrium.

[2]. Pearce, D. G., \& Schänzel, H. A. (2013). Destination management: The tourists' perspective. Journal of Destination Marketing \& Management, 2(3), 137-145.

[3]. Gúčik, M. (2010). Manažment cestovného ruchu. 2. vydání. Banská Bystrica: DALI-BB pre Slovak-Swiss Tourism.

[4]. Čuka, P. (2011). Základy teórie, metodológie a regionalizácie cestovného ruchu. Prešovská univerzita v Prešove, Vydavatel'stvo Prešovskej univerzity, (s 93).

[5]. Marine-Roig, E., \& Huertas, A. (2020). How safety affects destination image projected through online travel reviews. Journal of Destination Marketing \& Management, 18, 100469.

[6]. Dixit, S. K. (Ed.). (2020). The Routledge Handbook of Tourism Experience Management and Marketing. Routledge.

[7]. Kateřina, R., Michal, B., \& Ida, V. (2011). Cestovní ruch-podnikatelské principy a príležitosti $v$ praxi. Grada Publishing as.

[8]. Novakova, B. (2016). Destination Management and Competitiveness of Destinations. 8th International Annual Scientific Conference on Hotel Services, Tourism and Education, 144-150.

[9]. Rita, P., \& António, N. (2020). Promotion of inclusive tourism by national destination management organizations. Worldwide Hospitality and Tourism Themes, 12(6), 701-714.

[10]. Gong, J., \& Wang, J. (2020, December). Study on the influence of heterogeneous perception of tourist destination on tourists' local attachment and loyalty: Take Enshi in Hubei province as an example. In Proceedings of the 2020 3rd International Conference on E-Business, Information Management and Computer Science (pp. 497-503).

[11]. Srivastava, M., \& Fernandes, S. (2021). Using Preferred Destination Attributes to Segment the Religious Tourists, Visiting Sacred Cities. International Journal of Hospitality \& Tourism Systems, 14(2).

[12]. Kučerová, J. (2015). Plánovanie a politika v ciel'ových miestach cestovného ruchu. Banská Bystrica.

[13]. Majerova, J. et al. (2021). Behavioral aspects of brand management. Addleton Academic Publishers.

[14]. Loučanová, E., Šupín, M., Čorejová, T., RepkováŠtofková, K., Šupínová, M., Štofková, Z., \& Olšiaková, M. (2021). Sustainability and Branding: An Integrated Perspective of Eco-innovation and Brand. Sustainability, 13(2), 732.

[15]. Gaborik, P. (2021). Increasing the attractiveness of the selected region through destination marketing: master thesis. University of Zilina. 